\section{Farm Type and High Tunnel Management: Connections between Farm Characteristics and High Tunnel Outcomes in Indiana}

\author{
Analena B. Bruce ${ }^{1}$, Elizabeth T. Maynard ${ }^{2}$, Julia C.D. Valliant ${ }^{3}$, \\ and James R. Farmer ${ }^{4}$
}

ADDITIONAL INDEX wORDs. case study, hoophouse, human dimensions, protected agriculture, season extension, technology adoption

Summary. High tunnels are a low-cost technology that can strengthen local and regional food systems and have been shown to help farmers extend the growing season and increase the yield and shelf life, and improve the quality of their crops. This study addresses a need for a better understanding of farmers' experience with integrating high tunnels into their operations, to understand the human dimensions of high tunnel management. We present an analysis of survey and interview data to examine how farm characteristics affect the outcomes of growing specialty crops in high tunnels. Our findings show that farmers managing different types of farms have taken distinct approaches to integrating and managing high tunnels on their farms, with important implications for farm-level outcomes. We identify three types of farms commonly adopting high tunnels in Indiana: 1) alternative food and agriculture enterprises (AFAEs) are consumer-oriented, smallscale farms that sell their products directly to their customers in relationship-based market networks such as farmers' markets and community-supported agriculture; 2) mixed enterprise farmers have larger operations and sell into both conventional commodity markets and direct markets; and 3) side enterprise farmers operate small-scale enterprises and their primary household income comes from off-farm employment or another business. Farm type is associated with divergent levels of time and labor investment, resulting in higher capacity use of high tunnels and greater financial return for AFAE farmers who make high tunnels central to their business, compared with mixed and side enterprise farmers who invest less time and labor into their high tunnels. We explain how farm characteristics and approaches to adopting the infrastructure shape farmers' success and high-capacity use of high tunnels.

$\mathrm{H}$ igh tunnels are a low-cost technology that can strengthen local and regional food systems

Received for publication 22 Feb. 2021. Accepted for publication 1 Apr. 2021.

Published online 18 August 2021

${ }^{1}$ Department of Agriculture, Nutrition, and Food Systems, University of New Hampshire, 129 Main Street, Durham, NH 03824

${ }^{2}$ Department of Horticulture and Landscape Architecture, Purdue University, 625 Agriculture Mall Drive, West Lafayette, IN 47907

${ }^{3}$ The Ostrom Workshop, Indiana University, 513 N. Park Avenue, Bloomington, IN 47408

${ }^{4} \mathrm{O}$ 'Neill School of Public and Environmental Affairs, Indiana University, 1315 E. 10th Street, Bloomington, IN 47405

This work was supported by the Indiana State Department of Agriculture Specialty Crops Block Grant program under Grant \# SCBG-15-002. The funder played no role in the study.

A.B.B. is the corresponding author. E-mail: Analena.bruce@unh.edu.

This is an open access article distributed under the CC BY-NC-ND license (https://creativecommons. org/licenses/by-nc-nd/4.0/).

https://doi.org/10.21273/HORTTECH04783-21 by facilitating the production of highquality fruits and vegetables during the growing season and extend production during the cool/cold or rainy seasons of the year. A high tunnel is a plastic-covered structure for growing plants that is typically constructed directly over the soil, heated by passive solar energy and distinct from a low tunnel (a small structure that covers a single bed or row) or a heated greenhouse (Janke et al., 2017). High tunnels provide a protected environment for plants, shielding them from adverse weather, buffering low temperatures, and reducing certain diseases and pests (Lamont, 2009). High tunnels have been shown to help farmers extend the growing season and increase the yield and shelf life, and improve the quality of their crops (Belasco et al., 2013; Bruce et al., 2017; 2019a; O'Connell et al., 2012), and more farms are growing crops under cover. The number of U.S. farm operations growing under cover tripled between 1998 and 2019, as did the area grown under cover and the value of sales from these crops [U.S. Department of Agriculture (USDA), National Agricultural Statistics Service, 2021].

High tunnels are popular among small-scale, diversified farms that market their products directly to consumers, likely because the capacity to offer fresh produce more consistently throughout the year assists them in developing their customer base (Ahearn and Newton, 2009; Carey et al., 2009; Foust-Meyer and O'Rourke, 2015). High tunnels also help farmers increase their income by offering out-of-season, local produce that generates a premium price (Carey et al., 2009; Conner et al., 2010). Therefore, high tunnel technology has received attention for its potential to support the viability of direct market farms and increase the availability of fresh fruits and vegetables, both of which are needed for building robust local and regional food systems (Colasanti and Hamm, 2010; Conner et al., 2009; Mount, 2012). Because of their potential for enhancing specialty crop production, building high tunnel capacity can assist both farmers in capturing greater market share and consumers in accessing fresh, locally grown products over an extended period, potentially yearround.

Despite potential benefits, high tunnel production requires specialized knowledge and experience for successful implementation (Conner et al., 2010; Janke et al., 2017; Waldman et al., 2012), and could potentially be challenging to integrate with existing crop production systems. Growing specialty crops in a high tunnel is similar to growing them in the field, but there are enough substantial differences that one cannot use exactly the same methods in

\begin{tabular}{llll}
\hline $\begin{array}{l}\text { Units } \\
\begin{array}{l}\text { To convert U.S. to SI, } \\
\text { multiply by }\end{array}\end{array}$ & U.S. unit & SI unit & $\begin{array}{l}\text { To convert SI to U.S., } \\
\text { multiply by }\end{array}$ \\
\hline 0.4047 & acre $(\mathrm{s})$ & $\mathrm{ha}$ & 2.4711 \\
0.3048 & $\mathrm{ft}$ & $\mathrm{m}$ & 3.2808 \\
0.0929 & $\mathrm{ft}^{2}$ & $\mathrm{~m}^{2}$ & 10.7639
\end{tabular}


a high tunnel environment (Conner and Demchak, 2018). Previous studies have surveyed farmers about the management practices they use in their high tunnels (Knewtson et al., 2010), and explored the profitability of high tunnels (Galinato and Miles, 2013; Sydorovych et al., 2013; Vescera and Brown, 2016; Waldman et al., 2012). These studies have pointed to labor-related issues as barriers to increased high tunnel production and maximizing profit potential for farmers (Conner and Demchak, 2018; Conner et al., 2010; Knewtson et al., 2010). In addition, researchers identified management practices related to the timing of farmers' labor investment in high tunnels relative to the growing season and local markets as issues that warrant further research (Waldman et al., 2012). Other studies have identified long-term soil fertility and higher input costs as important challenges that affect high tunnel profitability (Fitzgerald and Hutton, 2012; Knewtson et al., 2012; Rudisill et al., 2015). The findings from these previous studies point to the need for qualitative research focused on better understanding the challenges that constrain farmers' effective management of high tunnels.

Research-based knowledge about the human dimensions of high tunnel adoption is limited. We are not aware of any studies that have examined how farm-level characteristics affect high tunnel management and profitability. Furthermore, there are no studies that consider the approaches farmers are taking to integrate high tunnels into their farm businesses. This study was designed to understand the farm characteristics, contextual conditions, and management approaches that make it more likely a particular high tunnel enterprise will be successful. The research question was: How do farm characteristics affect outcomes of growing specialty crops in high tunnels?

Many areas of agricultural scholarship have explored the relationship between farm characteristics and a variety of outcomes, such as farmers' success with new technology, innovations, and practices (Barnes et al., 2011; Emtage et al., 2007; Whatmore, 1994). Research studies have emphasized the importance of farm characteristics for farmers' success with a range of diversification strategies, as well as how farmers' approach to diversification varies by internal farm attributes (Carter, 2001; McElwee and Bosworth, 2010; Valliant et al., 2017).

Rural sociological literature distinguishes farms based on their marketing strategies, farm size, and scale, and makes a distinction between full and side enterprise farmers (Heimlich and Brooks, 1989; Inwood and Sharp, 2012). For instance, in a study conducted in the neighboring state of Ohio, researchers identified the following three types of farms: 1) alternative enterprises: small in size with high-value outputs, 2) recreational enterprises: very small scale, operated by hobby farmers, and 3 ) traditional enterprises: larger operations engaged in conventional commodity production (Inwood and Sharp, 2012). This study informed our identification of three types of farms with distinct approaches to high tunnel management.

\section{Materials and methods}

This article presents findings from the survey and case study phases of a mixed methods study of farmers using high tunnels in Indiana, which was conducted by a team of researchers from Indiana University and Purdue University (Farmer et al., 2016). The research included a survey of Indiana farmers using high tunnels and a follow-up case study of a subset of 20 farmers who responded to the survey. The survey was distributed to all high tunnel growers in Indiana identified by the research team, totaling 178 , based on available records from the Indiana Natural Resources Conservation Service (NRCS) office, Purdue University Extension, and personal contacts of the research team (see Bruce et al., 2019a for details about survey sampling and distribution).

The interviews analyzed in this article were part of the case study designed as a follow-up to the survey with the goal of understanding potentially divergent outcomes of growing specialty crops in high tunnels. The lead author visited 20 farms for the case study and spent half a day at each farm, touring the high tunnel(s) on each farm, learning about how farmers managed their high tunnels through a structured questionnaire that covered all aspects of high tunnel management along with horticultural data collection. In addition, they conducted semi-structured, in-depth interviews lasting 30 to $90 \mathrm{~min}$ with the manager and/or $\mathrm{CO}^{-}$ managers of each farm. A strength of qualitative methods is the capacity to provide greater depth to explain patterns identified in quantitative data, such as a survey (Miles and Huberman, 1994). The interviews were designed to answer the research question: How do farm characteristics affect outcomes of growing specialty crops in high tunnels?

To answer this research question, farms were selected to participate in the case study, based on the logic of a multiple case study approach that predicts contrasting results but for predictable reasons (theoretical replication), to identify divergent patterns in high tunnel usage (Stake, 1995). Specifically, the farms were selected for the case study based on attributes identified in the survey, including full-time vs. side enterprise farmers (measured as percentage of household income derived from off-farm employment), years of farming experience, percentage of income derived from high tunnels, and the number of high tunnels used on the farm. We use the USDA's revised definition of farm size based on gross farm income (Hoppe and MacDonald, 2013), as well as the number of acres farmed to capture the farms' relative size and scale, given that both these aspects are important for understanding the diversity of farms in our study. Contextual differences were also considered, to capture a range of farms that varied by proximity to urban markets, farm products (commodity grain crops, livestock, specialty crops), and production practices (organic vs. conventional farming practices). Outcomes of interest were high-capacity use of high tunnels, including positive outcomes for farmers in terms of estimated yield increases, farm income, season extension, year-round production, and quality of life or overall experience with high tunnels.

The analysis in this article is based on data from the interviews and the survey. The interviews with farmers focused on farmers' perception of the most salient human dimensions that influence high tunnel management. The interviews were transcribed verbatim and coded and analyzed with qualitative analysis software (NVivo; QSR International, Melbourne, 
Australia). The coding process was conducted by the lead author and included an initial read to identify general themes, a second reading and initial coding for important themes and topics, and a third reading and coding phase that refined the initial coding categories into general categories and subcategories, based on emerging themes (Creswell and Poth, 2017; Miles and Huberman, 1994). The final list of codes was crosschecked by a member of the research team. The analysis is based on farm characteristics identified from the survey data that were matched to the farms that participated in the interviews, and the analysis of farm-level outcomes is based on the qualitative interview data.

\section{Results}

In this article, we focus our analysis on the results from the case study, using descriptive data from the survey to identify three approaches to high tunnel management and divergent farm-level outcomes of high tunnel adoption. The survey data are based on 103 useable surveys from an adjusted sample of 164, resulting in a $62.8 \%$ response rate (Bruce et al., $2019 b$ ). We identify three types of farms based on the characteristics of farm enterprises identified in the study by Inwood and Sharp (2012), using our survey data. Next, we show that each type of farm is using a different approach to integrating high tunnels into their farms. We explore the connections between the type of farms using high tunnels and their outcomes, measured as the reported income generated from their high tunnels and income per square foot of high tunnel space. To our knowledge, this is the first study to investigate the different approaches farmers are taking to add a high tunnel to their farm. It is also the first study that examines the connections between the characteristics of farm enterprises and successful high tunnel outcomes.

In this section, we first describe the general characteristics of the farms that participated in the case study, based on data collected in the survey. Next, we describe three different types of farm enterprises that match three types of farms identified in the rural sociological research literature (Hemlich and Brooks, 1989; Inwood and Sharp,
2012). These farm types are characterized based on their marketing strategy, percentage of household income from off-farm employment, gross farm income, and acres. We then describe the relationship between farm type and approach to high tunnel adoption. We demonstrate how the three types of farms have taken different approaches to integrating high tunnels, based on the centrality of high tunnels to the farm business. We also explore differences in high tunnel management, measured by diversity of crops grown in high tunnels and differences in the use of organic practices and season extension. Here we explain how the different approaches to high tunnel adoption shape the level of investment farmers make in the infrastructure and their experiences with using it. Finally, we examine how farmers' approaches to high tunnel adoption shape their high tunnel outcomes. Our analysis helps explain farmers' success with high tunnels, based on the interview findings and measured by income per square foot of high tunnel space.

\section{General characteristics of farms included in case study}

The farms included in our case study varied widely and ranged from large farms that produced grain and hay crops as well as specialty crops and apple (Malus $\times$ domestica) orchard enterprises for wholesale markets and direct-to-consumer sales, to small farms that focused on specialty crop production for direct markets. Accordingly, the farms ranged in size and scale from farms of less than 10 acres to farms of up to 1000 acres, and farms with a gross farm income of less than $\$ 5000$ up to farms with a gross farm income of up to $\$ 1$ million. The farms also ranged in their proximity to urban markets. Next, we categorize the farms in our study into three types, based on the following characteristics: marketing strategy, percentage of household income from off-farm employment, gross farm income, and acres.

\section{Three types of farm enterprises adopting high tunnels in Indiana}

Type 1: Alternative FOOD AND AGRICULTURE ENTERPRISES. AFAEs are consumer-oriented, smallscale farms that sell their products directly to their customers in relationshipbased market networks such as farmers' markets and community-supported agriculture (CSA) (Inwood and Sharp, 2012). The AFAE farmers are typically first-generation farmers or farmers who grew up on a farm and left to pursue nonfarm careers but returned to agriculture later in life because of new opportunities with the rise of the local food movement (Bruce, 2019). These farmers exemplify a growing sector of agriculture characterized in the influential book, The Lean Farm (Hartman, 2015). The AFAE farmers identified in this research are unique in the Indiana context because they focus on specialty crops, which represent just $0.3 \%$ of acres of agricultural production in Indiana, and do not engage in conventional commodity production, which is predominant in the state. Instead, these farmers practice a form of high-value, intensive production with an emphasis on diversity and sustainability, contributing to the continuing increase in direct-to-consumer sales in Indiana and nationwide since 1992 (Thilmany et al., 2021).

Overall, AFAE farmers had a strong understanding of their markets and had developed a market niche that fit well with their business focus and customer base. Most of them $(67 \%)$ were within a 30 -min drive of an urban area with more than 50,000 residents, and thus often had access to high-value, urban farmers' markets and farm-to-table restaurants that operated through the off-season. Many AFAE farmers also sold their products through winter CSAs, food service providers, or other businesses that provide a year-round market, including institutional buyers, such as a food service company, and through a business subscription program.

AFAE farmers also shared a number of other characteristics. All of them relied on their farms for most of their household income, and all had gross farm income of at least $\$ 50,000$ (Table 1). AFAE farmers fit the USDA definition of small family farms, with $67 \%$ in the subcategory of low sales (defined by USDA as less than $\$ 150,000), 17 \%$ in the moderate sales subcategory (defined by USDA as $\$ 150,000-\$ 349,999$ ) and $17 \%$ meeting USDA's definition of midsize farms with a gross farm income of $\$ 350,000$ to $\$ 499,999$ (Hoppe and MacDonald, 2013). Most AFAE farmers managed 
Table 1. Marketing strategy, off-farm income, gross income, and acres farmed for three types of farm enterprises that participated in a survey and interviews about high tunnel adoption in Indiana.

\begin{tabular}{|c|c|c|c|c|}
\hline Type of farm & Marketing strategy & $\begin{array}{c}\text { Majority income } \\
\text { earned on-farm vs. } \\
\text { off-farm }\end{array}$ & Farm gross income & Area farmed ${ }^{\mathrm{z}}$ \\
\hline $\begin{array}{l}\text { Type } 1 . \text { Alternative food } \\
\text { and agriculture } \\
\text { enterprises (AFAEs): } \\
\text { small, consumer- } \\
\text { oriented, selling to } \\
\text { direct markets }(\mathrm{N}=6 \text { ) }\end{array}$ & $\begin{array}{l}100 \% \text { direct-to- } \\
\text { consumer via farmers' } \\
\text { markets, community- } \\
\text { supported agriculture } \\
\text { (CSA), business } \\
\text { subscription service } \\
\text { and restaurants }\end{array}$ & $\begin{array}{l}100 \% \text { majority of } \\
\text { income earned on- } \\
\text { farm }\end{array}$ & $\begin{array}{l}66.6 \%: \\
\$ 50,000-\$ 149,000 \\
16.6 \%: \\
\$ 150,000-\$ 345,999 \\
16.6 \%: \\
\$ 350,000-\$ 499,999\end{array}$ & $\begin{array}{l}66.6 \% \text { : less than } 10 \text { acres } \\
16.6 \%: 10-15 \text { acres } \\
16.6 \%: 100-500 \text { acres }\end{array}$ \\
\hline $\begin{array}{l}\text { Type 2. Mixed enterprises: } \\
\text { larger operations selling } \\
\text { into both conventional } \\
\text { commodity markets and } \\
\text { direct markets }(\mathrm{N}=4)\end{array}$ & $\begin{array}{l}\text { Conventional } \\
\text { commodity market } \\
\text { for field crops } \\
\text { livestock and } \\
\text { wholesale apples, } \\
\text { direct-to-consumer } \\
\text { via farm stand, } \\
\text { farmers' market and } \\
\text { agritourism }\end{array}$ & $\begin{array}{l}50 \% \text { majority of income } \\
\text { earned off-farm } \\
50 \% \text { majority of income } \\
\text { earned on-farm }\end{array}$ & $\begin{array}{l}50 \%: \\
\quad \$ 350,000-\$ 499,999 \\
50 \%: \\
\quad \$ 500,000-\$ 999,999\end{array}$ & 100\%: 500-1,000 acres \\
\hline $\begin{array}{l}\text { Type } 3 \text {. Side enterprises: } \\
\text { very small scale, } \\
\text { operated by part-time } \\
\text { farmers }(\mathrm{N}=10)\end{array}$ & $\begin{array}{l}\text { Direct-to-consumer via } \\
\text { farmers' markets, } \\
\text { CSA, restaurants and } \\
\text { on-farm stands }\end{array}$ & $\begin{array}{l}100 \% \text { majority of } \\
\text { income earned off- } \\
\text { farm }\end{array}$ & $\begin{array}{l}10 \% \text { : less than } \$ 5,000 \\
30 \%: \$ 5,000-\$ 9,999 \\
50 \%: \$ 10,000-\$ 49,999 \\
10 \% \text { : } \\
\quad \$ 50,000-\$ 149,000\end{array}$ & $\begin{array}{l}\text { 20\%: not reported } \\
40 \% \text { : less than } 10 \text { acres } \\
30 \%: 15-35 \text { acres } \\
10 \%: 60-65 \text { acres }\end{array}$ \\
\hline
\end{tabular}

${ }^{\mathrm{z}} \mathrm{l}$ acre $=0.4047$ ha.

smaller-acreage farms, with $67 \%$ being less than 10 acres. All the AFAE farmers in our study focused exclusively on specialty crops, including vegetables, fruits, cut flowers, herbs, and bedding plants; none of them had livestock or commodity grain crops. Finally, most $(83.3 \%)$ of AFAE farmers were using organic practices (whether certified or not) as a way of differentiating their products and catering to the increased consumer interest and demand for organic or naturally grown products (Table 2 ).

Type 2: Mixed enterprises. The farmers with mixed enterprises, hereafter mixed enterprise farmers, were larger operations selling into both conventional commodity markets and direct markets (Inwood and Sharp, 2012). They included established commodity, livestock, and specialty crop farmers who had expanded or added a direct-to-consumer line of products as a diversification strategy on their farms. For instance, they produced field crops for the conventional commodity market but also produced some specialty crops they marketed directly to their customers in an onfarm stand and at farmers' markets. This trend of mixed enterprise farmers adding a direct market product line is significantly contributing to the increase in direct-to-consumer sales (Thilmany et al., 2021). In contrast to the AFAE farmers, most $(66.7 \%)$ of whom were near an urban area, half of the mixed enterprise farmers were within a 30-min drive of an urban area and half were outside of a $30-\mathrm{min}$ drive. Mixed enterprise farmers who were more than 30 min away from an urban area often lacked access to winter markets, or the winter markets in their area were small and infrequent, thus limiting opportunities for season extension to generate income from sales.

The mixed enterprise farmers share a number of characteristics: their gross farm income is much higher than the AFAE farms, ranging from $\$ 350,000$ to $\$ 999,999$, with half in the $\$ 350,000$ to $\$ 499,999$ range and the other half in the $\$ 500,000$ to $\$ 999,999$ range, putting all mixed enterprise farms in the "midsize" category (Hoppe and MacDonald, 2013). They also managed more acres, 500 to 1000 , than the other farmers in this study. Of the mixed enterprise farms, half earned most of their income from off the farm, and the other half earned less than most of their household income from off the farm (Table 1). In contrast to the AFAE farmers of whom $83.3 \%$ used organic practices, none of the mixed enterprise farmers were using organic practices (Table 2).

Type 3: Side enterprises. Side enterprise farmers operated small-scale enterprises and their primary household income came from off-farm employment or another business (Inwood and Sharp, 2012). Of the side enterprise farmers, most $(70 \%)$ were located in rural areas farther than 30 min from an urban area of at least 50,000 and therefore had the least access to urban markets. Consequently, many of them were far from winter farmers' markets and farm-to-table restaurants, and few of them had attempted a winter CSA. Even though some of the side enterprise farmers in rural areas had also developed a strong niche in local markets, the earnings potential they described from rural farmers' markets was lower than what farmers described earning in urban markets. Thus, side enterprise farmers who were using high tunnels in rural areas were constrained by their distance from urban farmers' markets with higher earning potential and by their lack of access to winter markets.

Most side enterprise farmers operated farms that were smaller in scale than the previous two categories and 
Table 2. Approach of high tunnel (HT) adoption and crop management for three types of farm enterprises that participated in a survey and interviews about high tunnel adoption in Indiana.

\begin{tabular}{|c|c|c|c|c|c|}
\hline Type of farm & Approach to HTs & $\begin{array}{c}\text { Avg HTs on farm } \\
\text { (no.) }\end{array}$ & $\begin{array}{c}\text { Crop diversity in } \\
\text { HT }\end{array}$ & Organic or not & $\begin{array}{c}\text { Season extension } \\
\text { or not }\end{array}$ \\
\hline $\begin{array}{l}\text { Type 1. Alternative } \\
\text { food and agriculture } \\
\text { enterprises } \\
\text { (AFAEs): small, } \\
\text { consumer-oriented, } \\
\text { selling to direct } \\
\text { markets }(\mathrm{N}=6)\end{array}$ & $\begin{array}{l}\text { Center of business } \\
\text { on small farm }\end{array}$ & 5 & $\begin{array}{l}83 \% \text { : more than } 5 \\
\text { crops } \\
16.6 \%: 3-5 \text { crops }\end{array}$ & $\begin{array}{l}\text { 83.3\%: Yes } \\
\text { 16.6\%: No }\end{array}$ & $100 \%$ : Yes \\
\hline $\begin{array}{l}\text { Type } 2 . \text { Mixed } \\
\text { enterprises: larger } \\
\text { operations selling } \\
\text { into both } \\
\text { conventional } \\
\text { commodity markets } \\
\text { and direct markets } \\
(\mathrm{N}=4)\end{array}$ & $\begin{array}{l}\text { Side business on } \\
\text { midsize farm }\end{array}$ & 2.75 & $\begin{array}{l}75 \%: 3-5 \text { crops } \\
25 \%: 1-2 \text { crops }\end{array}$ & $\begin{array}{l}0 \%: \text { Yes } \\
100 \%: \mathrm{No}\end{array}$ & $\begin{array}{l}\text { 25\%: Yes } \\
75 \%: \text { No }\end{array}$ \\
\hline
\end{tabular}

meet the USDA definition of a small family farm in the subcategory of offfarm occupation (Hoppe and MacDonald, 2013). The side enterprise farmers had smaller farms than the AFAE and mixed enterprise farmers, reporting a gross farm income ranging from $\$ 5000$ to $\$ 49,999$, with one farmer reporting a gross income between $\$ 50,000$ and $\$ 149,000$ because they also jointly managed a family business that included specialty crop production and a farm store that was separate from their small farmbased side business involving the high tunnel (Table 1). All of the side enterprise farmers earned most of their household income from off-farm sources, in contrast to the AFAE and half of the mixed enterprise farmers. In terms of acreage, side enterprise farmers tended to be smaller than the mixed enterprise farmers, with $40 \%$ less than 10 acres and $30 \%$ less than 35 acres. The side enterprise farmers varied in their approach to organic practices, with most $(60 \%)$ using organic practices and the rest not.

\section{Farm type and approach to adopting high tunnels}

In this section, we analyze the relationship between the type of farm enterprise and farmers' approach to adopting high tunnels on their farm.
We demonstrate the three different approaches to adopting high tunnels, based on the centrality of high tunnels to the farm business. The centrality of high tunnels to the farm business is operationalized by the percentage of farm income that farmers earned from their high tunnels. We also discuss differences in farmers' crop management in their high tunnels, including the diversity of crops grown in high tunnels, and the use of organic practices and season extension. It is important to note the farmers in our case study did not differ greatly in terms of how much experience they had with managing high tunnels, with an average of 3.16 years for AFAE farmers, 3 years for mixed enterprise farmers, and an average of 2.66 years for side enterprise farmers.

High TUNNEL APPROACH 1 : AFAEs. The AFAE farmers made high tunnels a central part of their farm business. Based on the in-depth interviews with these farmers, the focus of their farm business was their high tunnel production (Table 2). This is evidenced by the number of high tunnels the AFAE farmers managed, between two and seven high tunnels on their farms, with an average of five. All the AFAE farmers grew some crops in the field but focused the most significant time and management into their high tunnel crops and used their high tunnel crops to enhance the rest of their farm business in complementary ways.

A clear motive for making high tunnels a central part of their farm business was the potential for extending the growing season and increasing farm income in the off-season. For AFAE farmers, the season extension and year-round production they achieved in their high tunnels supported their ability to rely on their farms for most of their household income by allowing them to increase their farm income and earn income for more months of the year. For example, they increased the number of months they could offer their CSA, or the number of months they could supply wedding flowers, in the case of a flower farm. One farmer said:

They [high tunnels] have been fabulous I mean for growing my business they allowed me to start doing winter market and having income in the winter and not being somewhat impoverished by the time May opened up because back in those days the market just ran from May-October, 6 months out of the year. Oh my gosh it's expanded my income so much. It's allowed me to do (weddings) sales in November and December and March (19 Oct. 2016).

One farmer used the high tunnels to grow early season strawberries 
(Fragaria $\times$ ananassa) to attract customers at the farmers' market and increase their strawberry sales at the peak season by building a loyal customer base. Several of the farmers used season extension to offer an assortment of greens and root crops during the cold season to extend their farm income and increase their customer base.

In comparison with the other types of farm enterprises, the AFAE farmers also managed their high tunnels differently, maintaining a higher level of crop diversity in their high tunnels. Specifically, $83 \%$ of AFAE farmers produced more than five crops, and the rest produced at least three to five crops. In the interviews, they explained they maintained a high level of diversity of high tunnel crops as well as markets, and they saw this diversity as important to their success. The diversity lowered their financial risk when they suffered crop loss or failure from extreme weather, or when they lost business in one of their markets, such as when a farmers' market was rained out for an entire month in the peak season, or when a chef changed the menu and thus the restaurant's product needs.

High TUNNEL APPROACH 2: Mixed enterprises. A second approach to integrating high tunnels into a farm was taken by mixed enterprise farmers who had commodity grain crops, livestock, and/or horticultural crops, and added high tunnels as a diversification strategy to complement their existing farm business. For example, one farm family had a commodity grain and sustainable livestock operation and started growing more vegetables and going to the farmers' market, and then acquired a high tunnel. This diversification allowed them to supplement their farm income to support their adult child who had returned to the farm, in addition to the primary operator who stopped working an offfarm job and started farming full-time.

Likely because high tunnels were less central to their farm businesses, mixed enterprise farmers invested less time and money into high tunnels than their AFAE farmer counterparts.

Mixed enterprise farmers managed a range of one to three high tunnels on their farms, with an average of 2.75 , compared with the average of five high tunnels per farm for the AFAE farmers (Table 2). Mixed enterprise farmers also took a different management approach than the AFAE farmers, using their high tunnels primarily for increasing the yield and quality of summer fruiting crops, mainly tomatoes (Solanum lycopersicum). Most mixed enterprise farmers $(75 \%)$ focused on three to five crops, such as tomatoes, bell peppers (Capsicum annuum), or cucumbers (Cucumis sativus), often focusing on just two main crops and planting one or two other crops in a small corner of their high tunnel for household consumption, recreation, or experimentation. Several of the mixed enterprise farmers had experimented with other summer fruiting crops before settling on tomatoes and/or bell peppers. Just one of the farmers in this category used their high tunnels to produce fall leafy greens crops in addition to tomatoes.

High tUNNEL APPROACH 3: Side ENTERPRISE ENTERPRISES. A third way farmers adopted high tunnels was as the central focus of a side business, operated by a side enterprise farmer. Side enterprise farmers operated an average of one to four high tunnels, with an average of 2.77 high tunnels per farm. Side enterprise farmers took a more varied approach to crop diversity than the AFAE or mixed enterprise farmers, with $20 \%$ producing just one or two crops, $20 \%$ producing three to five crops, and $60 \%$ producing more than five crops (Table 2 ).

For side enterprise farmers, high tunnels are an important part of their farm business, but they work off-farm jobs for their primary income. For example, one side enterprise farmer put up two high tunnels on their property to use as a side business they manage along with a home-based family business. This farmer describes the decision to purchase the property for lifestyle and family goals, and that they never intended to be farmers:

We bought it [the land] with the intention that it had possibilities ... it had possibilities for the lifestyle that we wanted, good place to raise kids out in the country, room that we could do something with. I guess I would say that probably market farming wasn't really ... I probably wouldn't have had that in mind necessarily. I wouldn't have envisioned it just like it is now, but kind of the opportunity presented itself.
When asked why they decided to put up the high tunnels they said:

As far as the high tunnels, the fella I worked for put one up and had tomatoes in it a couple of years while I was working for him. So that kind of made me think hey this is something we could do (8 June 2017).

High tunnels were also an entry point for beginning farmers who did not plan to become full-time farmers but were operating small-scale farms or homesteading operations. One side enterprise farmer who is also a beginning farmer described how they decided to invest in a high tunnel:

I read Eliot Coleman's book, Four Season Gardening, and it tripped a switch in my mind, I'm sure I could do that, if I could get a hoophouse. The government program came available just as soon as I finished that book. And I was the first one to run over there and said okay, sign me up. And here we are (19 Aug. 2016).

This side enterprise farmer has two high tunnels that are the main site of production on their small homestead.

Some of the side enterprise farmers are beginning farmers with aspirations of farming full-time. For the beginning farmers in this category, high tunnels have served as an entry point to become established as farmers by giving them a tool to produce specialty crops intensively in a small space and maximize their use of a small land base. For example, a side enterprise and beginning farmer describes how he used the cost-share incentive to create two high tunnels:

One high tunnel went up the first year. That was one I just kind of makeshift built on my own and that shows. I got a grant for a $14 \times 72[\mathrm{ft}]$ which I split up into two high tunnels from the NRCS in 2013. I have those for vegetable only production. You can only see one of those. That's the high one here. The other one is farther down. I split them up because of one, the geography, and two, kind of testing different sites on the farm to see where things grow better (24 Oct. 2016).

In this example and others like it, the high tunnel provided a tool for experimenting, learning and growing as a new farmer.

\section{Farm enterprise type explains high tunnel outcomes}

In this section, we demonstrate the relationship between farmers' approach to high tunnel adoption and 
their high tunnel outcomes. Our analysis explains patterns of success and difficulty with high tunnels, based on farmers' experiences reported in the interviews and quantified as income per square foot of high tunnel space. Overall, farm characteristics influenced high tunnel adoption and farmers' goals and level of investment in the infrastructure. In general, investing sufficient time and labor into high tunnel management was an important factor in determining farmers' success with high tunnels. Farmers' approach to using high tunnels, measured as the centrality of high tunnels to the farm business, shapes the amount of time and labor they can give to managing their high tunnels, and consequently their patterns of success and difficulty.

Here we provide greater contextual detail and information on farmers' approach to high tunnel management and their outcomes. All the AFAE farmers emphasized their high tunnels were central to the success of their farm business. Consequently, AFAE farmers managed their high tunnels at a higher capacity, reporting $\$ 5.18 / \mathrm{ft}^{2}$ in income from their high tunnels on average (Table $3)$. They also reported higher annual sales, $\$ 10,000$ to $\$ 75,000$, from their high tunnel production than mixed enterprise and side enterprise farmers, who reported sales of $\$ 1000$ to $\$ 30,000$ (Table 3). AFAE farmers focused their farm business on high tunnels, and thus typically managed their high tunnels at a higher capacity, keeping them full or nearly full yearround, planting new crops in succession and thus maximizing their season extension potential. The AFAE farmers were most successful with high tunnel production in terms of their income per square foot of high tunnel space, as well as the sales from their high tunnels and the value they described that their high tunnels made to their overall farm business.

Mixed enterprise farmers added high tunnels as a diversification strategy to complement their commodity grain, livestock, or apple orchard enterprises. Because high tunnels were a smaller part of their farm business and not central, they generally invested less time and resources into them, which explains their comparatively lower outcomes. Mixed enterprise farmers reported lower income per square foot at $\$ 1.84 / \mathrm{ft}^{2}$ on average, compared with $\$ 5.18 / \mathrm{ft}^{2}$ for AFAE farmers. They also reported lower annual high tunnel sales than AFAE farmers, with $75 \%$ reporting $\$ 5000$ to $\$ 10,000$ in sales from their high tunnels (see Table 3 ). On average, side enterprise farmers earned $\$ 1.87 / \mathrm{ft}^{2}$ of high tunnel space, which is comparable to mixed enterprise farmers who operate midsize farms and have high tunnels as a side business (at $\$ 1.84 / \mathrm{ft}^{2}$ ) and lower than the $\$ 5.18 / \mathrm{ft}^{2}$ reported by AFAE farmers who make high tunnels central to their business (Table 3 ). The average sales and income per square foot reported for each category of farms in our analysis presented in Table 3 should be interpreted as useful descriptive data that are suggestive of relationships that could be tested with a generalizable sample in a follow-up analysis.

\section{Patterns of success and difficul- ty with high tunnel management}

The analysis also helps us understand how farmers' approach to integrating high tunnels on their farm shapes their experience with using them, and patterns of success and difficulty.

AFAE farmers struggled with the challenge of managing several high tunnels simultaneously, at an average of five high tunnels for the farmers in this category. For example, a farmer describes high tunnel management as easy overall, but challenged by the addition of two high tunnels, totaling six for their farm:

It became a little hard to juggle them once I got the two at the top up. There are days that I never even get up there other than harvesting, but there are days I think oh I should go up there, I need to check it because I always check the four right here that are clustered near my work area. It's kind of what I do just to take a breather. Keep my eyesight refocused. It's not that hard but I tend to not get up there as much. So there is a point of losing a little control the more high tunnels you put up and the more fields you open up and I've certainly experienced that not staying quite as on top of things or feeling like some things are wasted, never got harvested at a prime spot and might as well till them in [author emphasis] (19 Oct. 2016).

They note they lose crops from time to time because they were not able to invest adequate time and attention in their additional high tunnels. In addition, many of the AFAE farmers are also juggling their high tunnel production with their vegetable crops grown in the field. The complexity of managing multiple high

Table 3. Proportion of sales from high tunnels (HTs) and average income per square foot of high tunnels for three types of farm enterprises that participated in a survey and interviews about high tunnel adoption in Indiana.

\begin{tabular}{|c|c|c|c|}
\hline Type of farm & Approach to HTs & Sales from HTs & Avg income $\mathrm{z}^{\mathrm{z}}$ \\
\hline $\begin{array}{l}\text { Type } 1 . \text { Alternative food and } \\
\text { agriculture enterprises } \\
\text { (AFAEs): small, consumer- } \\
\text { oriented, selling to direct } \\
\text { markets }(\mathrm{N}=6)\end{array}$ & $\begin{array}{l}\text { Center of business on small } \\
\text { farm }\end{array}$ & $\begin{array}{l}33.3 \% \text { : not reported } \\
50 \%: \$ 10,000-\$ 50,000 \\
16.6 \%: \$ 70,000-\$ 75,000\end{array}$ & $\$ 5.18 / \mathrm{ft}^{2}$ \\
\hline $\begin{array}{l}\text { Type } 2 . \text { Mixed enterprises: } \\
\text { larger operations selling into } \\
\text { both conventional } \\
\text { commodity markets and } \\
\text { direct markets }(\mathrm{N}=4)\end{array}$ & Side business on midsize farm & $\begin{array}{l}25 \%: \text { not reported } \\
75 \%: \$ 5,000-\$ 10,000\end{array}$ & $\$ 1.84 / \mathrm{ft}^{2}$ \\
\hline $\begin{array}{l}\text { Type } 3 . \text { Side enterprises: very } \\
\text { small scale, operated by } \\
\text { part-time farmers }(\mathrm{N}=10)\end{array}$ & $\begin{array}{l}\text { Center of part-time or side } \\
\text { business }\end{array}$ & $\begin{array}{l}20 \%: \text { not reported } \\
60 \%: \$ 1,000-\$ 10,000 \\
20 \%: \$ 10,000-\$ 30,000\end{array}$ & $\$ 1.87 / \mathrm{ft}^{2}$ \\
\hline
\end{tabular}

${ }^{2} \$ 1.00 / \mathrm{ft}^{2}=\$ 10.7639 / \mathrm{m}^{2}$. 
tunnels in addition to field crops is difficult, as they have to coordinate these separate sites of production that are on different planting and harvesting timeframes. In addition, they were doing their own marketing, whether directly to consumers through farmers' markets and CSA programs, to local restaurants, and in many cases all three of these market outlets. Despite these challenges, they were highly successful with using high tunnels to extend the growing season and enhance their farm businesses in strategic ways through the high-capacity use of high tunnels.

Mixed enterprise farmers managing high tunnels as a side business in addition to a larger commodity-oriented farm struggled to give sufficient time and attention to their high tunnels, as their primary farming activities took most of their time. In general, with one exception, mixed enterprise farmers emphasized they struggled to allocate sufficient time and labor to managing their high tunnel products because they were primarily focused on the products that made up their farm's primary source of income, such as grain/forage crops or orchard products.

For example, a farmer described how the lack of winter markets in their area did not matter much to them because they did not have time to get all their high tunnel crops harvested. They described being too busy with operating their agritourism business, in addition to the commodity grain crops and vegetable crops grown in the field. In response to a question about how the farmers' market has fewer customers in the late summer, they replied:

It does and see we quit going. We get so busy here. I don't need to go up there to get rid of it anyway. I can't get it all picked as it is (13 June 2017).

The family puts all their efforts into managing the part of their farm business with greater financial return. Likewise, for a farm that includes a livestock operation and commodity grain crops, they have struggled to keep up with their high tunnel:

The first year was excellent. You get out of it what you put into it [author emphasis]. The second year we had a hailstorm come through in April and it blew the plastic off and it was windy for a week or two. We were out there with frost covers and we mudded it in and compacted it and so we've had a couple of bad years but if I'd paid closer attention, we would have done better (7 June 2017).

This farmer makes an important point that sums up the experience of farmers using high tunnels; the time and attention farmers could devote to their high tunnel was a pivotal factor that determined their success.

As a consequence of the lack of time and labor they had available for managing their high tunnels, some of the mixed enterprise farmers had high tunnels that were full of weeds, or structures sitting empty since the plastic had been ripped off by high winds and never replaced. In the interviews and on tours of their high tunnels these growers described not having time to harvest all the crops produced in their high tunnels and not finding sufficient time to maintain the tunnels to their maximum capacity. For example, in response to a question about why they put up a high tunnel, one farmer who managed an agritourism operation in addition to several hundred acres of commodity grain crops said:

We had been to some shows and they had talked about them. At that point we thought we wanted to be bigger vegetable growers than I really think I want to be now. I'll be honest, we've never used them to really, oh I mean we'll have tomatoes out of them but ... it doesn't matter one way or the other. I mean at one point I thought we wanted to do more and extend that season more. I mean if I had to grow a lot of vegetables, I'd be doing them all in a high tunnel (13 June 2017).

The farmer describes how they are not using their high tunnels to their greatest capacity because they are not producing vegetables to the extent they had envisioned when they purchased their high tunnels.

Side enterprise farmers described the challenge of juggling high tunnel production with field crops and offfarm employment. For example, one side enterprise farmer was also a teacher and maintained a farm business on the side, eventually putting up three high tunnels in addition to several acres of field crops. He says:

I've got room for more high tunnels [and previously described how he would grow everything in high tunnels if he could], but it's almost like you're making yourself more work than you can do. It's like I'd have to really think about it because if you do expand with that then you'd probably have to give up something else (29 June 2017).

As we see with this side enterprise farmer, the capacity to invest sufficient time and labor was the major limiting factor for expanding high tunnel production among side enterprise farmers.

\section{Discussion}

Overall, our findings provide greater depth of understanding and explanation for the conclusions of previous research studies of high tunnel management and economic outcomes (Conner and Demchak, 2018; Knewtson et al., 2010; Waldman et al., 2012). For instance, Waldman et al. (2012) identified a correlation between the amount of time and labor put into high tunnel management and the high-capacity use of high tunnels, and specifically that an important determinant of higher return on investment was the ability to keep the high tunnel full year-round. We provide an explanation for that finding, showing how the characteristics of the farm and their approach to integrating high tunnels into their farms influenced farmers' investment of sufficient time and labor into them. Specifically, farmers who operated consumer-oriented AFAE were more likely to use their high tunnels for season extension and year-round production and managed their tunnels at a higher capacity than other farmers, keeping them full almost year-round. Their management emphasis on high tunnels resulted in a higher income per square foot. In contrast, mixed enterprise farmers who added a high tunnel as a diversification strategy struggled to invest sufficient time and labor into their high tunnels to be successful, because their management focus was on their production systems that were most economically important. This finding is consistent with a recent study indicating compatibility and labor-related issues experienced by farmers attempting to integrate high tunnels with mechanized commodity crop production (Conner and Demchak, 2018). Side enterprise farmers had more varied experiences with high tunnels depending on how central they were to their business, but 
generally struggled to invest sufficient time and labor into their high tunnels because they were juggling off-farm work and other agricultural production systems simultaneously.

Providing an analysis of how farmers are integrating high tunnels into their farm operations is valuable for a few reasons. First, it allows us to better understand some of the factors that affect successful management of high tunnels. This is important because the agricultural research literature focused on high tunnel profitability emphasizes crop systems and varieties; pest, disease, and soil management issues; seasonal modifications; and infrastructure attributes. These study findings are generally obtained from research trials, yet our analysis suggests that the results from these studies might be different if they took the human dimensions of high tunnel adoption and management into account. Thus, our goal is not to provide a comprehensive examination of all factors that shape high tunnel profitability, but rather to provide a better understanding of how the characteristics of a farm and a farmer's approach to adopting high tunnels shapes their outcomes, as a cautionary consideration for ongoing agricultural research and extension education. This analysis builds on our recent article (Bruce et al., 2019b) in which we explored farmers' experiences of the challenges and opportunities of high tunnel production, by explaining the connections between farmers' experiences and the characteristics of their operations. This is one of the few social science studies of high tunnel outcomes that we are aware of, and provides an important contribution for the research literature by analyzing human dimensions that have not been adequately considered in the agricultural research literature on high tunnels.

Second, it can inform extension educators, NRCS educators, and other agricultural service providers who support farmers who are adopting high tunnels, giving them a better understanding of the potential outcomes of current approaches to adopting high tunnels. For example, discussing the farmer's existing operation and commitments with this information in mind will allow educators to better anticipate common challenges and help farmers assess their readiness to add a high tunnel to their farm. For example, a mixed enterprise farmer considering adding a high tunnel to diversify their operation and add an additional revenue stream should carefully consider if they have the time and labor capacity to manage crops in a high tunnel, given their primary focus on economically important commodity crops. An AFAE farmer considering the addition of a high tunnel when they already manage more than two or three should carefully consider if they have the time and labor capacity to keep up with another structure in their operation. AFAE farmers managing the complexity of diverse production systems and direct marketing will benefit from careful planning in terms of how well the timing and labor requirements of the crops planned for a new structure will fit in with their existing high tunnel and field production systems. A side enterprise farmer considering a high tunnel should carefully determine if they have enough time and labor capacity to manage a high tunnel along with their off-farm employment and other farm production systems. Finally, all types of farmers would benefit from careful consideration of their time and labor availability for managing a high tunnel in the early spring and late fall when the greatest opportunity for high tunnel revenue generation is realized, given that farmers often have different time and labor strategies during the off-season.

Thinking through issues such as seasonal time and labor availability and consideration for how high tunnel planting and harvesting schedules will fit with other farm activities will be a useful process for farmers considering a high tunnel. By exploring patterns of successful high tunnel outcomes, we were able to clarify important considerations for farmers who are investing in a high tunnel to think through before they take that step. Farmers who have made the investment in high tunnels and are not seeing the return on their investment that they hoped for could consider how much time and labor they are currently spending and their proximity and access to winter markets, as important considerations for decision-making going forward. Agricultural service providers may also wish to reference the Indiana High Tunnel Handbook authored by the research team, which summarizes these observations and provides a decision-making tool for farmers considering investment in a high tunnel (Bruce et al., 2018 ), in addition to the article authored by the research team that provides additional recommendations (Bruce et al., 2019b).

Our study also points to the importance of winter markets for farmers to maximize the return on their investment in high tunnels by maximizing their season extension potential. This is important because our findings support the conclusion of the Michigan study, that farmers practicing season extension are earning the highest effective wages from their high tunnels (Waldman et al., 2012). Our findings build on this work, showing that Indiana farmers located near urban areas who sold their products to winter farmers' markets and farm-totable restaurants were producing crops nearly year-round and subsequently increasing their farm income and overall farm viability. Future research should investigate whether there is sufficient consumer demand to support winter markets in areas where they are lacking in Indiana, and other areas with increased numbers of high tunnels. Research is also warranted to determine if farmers in rural areas would have the capacity to supply winter markets and thereby increase the productivity and earnings from their high tunnels, if robust winter markets were established.

In conclusion, we identified three types of farms using three distinct approaches to adopting high tunnels on their farms. These three approaches to high tunnel adoption were associated with differences in high tunnel crop management and have implications for the farm-level outcomes of adopting high tunnels. By identifying the characteristics of farm enterprises that influence their success and common challenges with high tunnels, we provide an explanation of the human dimensions of management that affect high-capacity use of high tunnels. Our article explains how divergent approaches and management result in different levels of time and labor investment in high tunnels, leading to higher income per square foot and greater overall success for some types of farms compared with others. In the big picture, our analysis shows that high tunnels can boost farm income and productivity, thereby increasing 
the viability of direct market farms and specialty crop production in Indiana and likely other states with similar agricultural contexts in the midwestern United States. Our work can inform efforts to support the wider adoption of high tunnels to address the seasonal constraints to scaling up local and regional food systems by allowing for extended fruit and vegetable production in climates like the midwestern and northeastern United States with a limited growing season (Mount, 2012).

\section{Literature cited}

Ahearn, M. and D. Newton. 2009. Beginning farmers and ranchers. U.S. Dept. Agr., Econ. Res. Serv. Bull. 53.

Barnes, A.P., J. Willock, L. Toma, and C. Hall. 2011. Utilizing a farmer typology to understand farmer behaviour towards water quality management: Nitrate vulnerable zones in Scotland. J. Environ. Plann. Mgmt. 54(4):477-494, doi: 10.1080/ 09640568.2010 .515880 .

Belasco, E., S. Galinato, T. Marsh, C. Miles, and R. Wallace. 2013. High tunnels are my crop insurance: An assessment of risk management tools for small-scale specialty crop producers. Agr. Resour. Econ. Rev. 42(2):403-418, doi: 10.1017/ S1068280500004445.

Bruce, A.B. 2019. Farm entry and persistence: Three pathways into alternative agriculture in southern Ohio. J. Rural Stud. 1(69):30-40, doi: 10.1016/ j.jrurstud.2019.04.007.

Bruce, A.B., J.R. Farmer, E.T. Maynard, and J.D. Valliant. 2019a. Using high tunnels to extend the growing season and improve crop quality and yield: Assessing outcomes for organic and conventional growers in the US Midwest. Intl. J. Agr. Mgmt. 8(2):45-55, doi: 10.5836/ijam/ 2019-08-45.

Bruce, A.B., E.T. Maynard, and J.R. Farmer. 2019b. Farmers' perspectives on challenges and opportunities associated with using high tunnels for specialty crops. HortTechnology 29(3):290-299, doi: 10.21273/horttech04258-18.

Bruce, A.B., E.T. Maynard, J.R. Farmer, and J. Carpenter. 2018. Indiana high tunnel handbook. 2 Apr. 2021. <https:// edustore.purdue.edu/item.asp? Item Number $=$ HO $-296-W>$.

Bruce, A.B., J.R. Farmer, E.T. Maynard, and J.D. Valliant. 2017. Assessing the impact of the EQIP High Tunnel Initiative. J. Agr. Food Syst. Community Dev. 7(3):159-180, doi: 10.5304/ jafscd.2017.073.012.
Carey, E.E., L. Jett, W.J. Lamont, T.T. Nennich, M.D. Orzolek, and K.A. Williams. 2009. Horticultural crop production in high tunnels in the United States: A snapshot. HortTechnology 19(1):37-43, doi: 10.21273/hortsci.19.1.37.

Carter, S. 2001. Multiple business ownership in the farm sector - Differentiating monoactive, diversified and portfolio enterprises. Intl. J. Entrep. Behav. Res. 7(2):43-59, doi: 10.1108/ 13552550110695552 .

Colasanti, K.J.A. and M.W. Hamm. 2010. Assessing the local food supply capacity of Detroit, Michigan. J. Agr. Food Syst. Community Dev. 1(2): doi: 10.5304/ jafscd.2010.012.002.

Conner, D.S. and K. Demchak. 2018. Farmer perceptions of tunnels for berry production: Management and marketing implications. HortTechnology 28(6):706-710, doi: 10.21273/HORTTECH04147-18.

Conner, D.S., A.D. Montri, D.N. Montri, and M.W. Hamm. 2009. Consumer demand for local produce at extended season farmers' markets: Guiding farmer marketing strategies. Renew. Agr. Food Syst. 24(4):251-259, doi: 10.1017/ S1742170509990044.

Conner, D.S., K.B. Waldman, A.D. Montri, M.W. Hamm, and J.A. Biernbaum. 2010. Hoophouse contributions to economic viability: Nine Michigan case studies. HortTechnology 20(5):877-884, doi: 10.21273/horttech.20.5.877.

Creswell, J.W. and C.N. Poth. 2017. Qualitative inquiry and research design: Choosing among five approaches. 5th ed. Sage Publ., Thousand Oaks, CA.

Emtage, N., J. Herbohn, and S. Harrison. 2007. Landholder profiling and typologies used in the development of natural resource management programs in Australia - A review. Australas. J. Environ. Manage. 13(2):79-94, doi: 10.1007/s00267-0050359-z.

Farmer, J.R., E.T. Maynard, J.D. Valliant, and J. Ellett. 2016. Specialty crops and high tunnels: Evaluating success and building future capacity. Indiana State Dept. Agr. Specialty Crop Block Grant SCBG-15-002.

Fitzgerald, C.B. and M. Hutton. 2012. Production practices and challenges with high tunnel systems in Maine. J. Natl. Assoc. County Agr. Agents 5(2).

Foust-Meyer, N. and M.E. O'Rourke. 2015. High tunnels for local food systems: Subsidies, equity, and profitability. J. Agr. Food Syst. Community Dev. 5(2):27-38, doi: 10.5304/jafscd.2015.052.015.
Galinato, S. and C. Miles. 2013. Economic profitability of growing lettuce and tomato in western Washington under high tunnel and open-field production systems. HortTechnology 23(4):453-461, doi: 10.21273/horttech.23.4.453.

Hartman, B. 2015. The lean farm: How to minimize waste, increase efficiency, and maximize value and profits with less work. Chelsea Green, White River Junction, VT.

Heimlich, R.E. and D.H. Brooks. 1989. Metropolitan growth and agriculture: Farming in the city's shadow. U.S. Dept. Agr., Econ. Res. Serv. AER-619.

Hoppe, R.A. and J. M. MacDonald. 2013. Updating the ERS farm typology. U.S. Dept. Agr., Econ. Res. Serv. EIB-110.

Inwood, S.M. and J.S. Sharp. 2012. Farm persistence and adaptation at the rural-urban interface: Succession and farm adjustment. J. Rural Stud. 28(1):107-117, doi: 10.1016/j.jrurstud.2011.07.005.

Janke, R.R., M.E. Altamimi, and M. Khan. 2017. The use of high tunnels to produce fruit and vegetable crops in North America. Agr. Sci. 8(07):692-715, doi: 10.4236/as.2017.87052.

Knewtson, S.J.B., E.E. Carey, and M.B. Kirkham. 2010. Management practices of growers using high tunnels in the central Great Plains of the United States. HortTechnology 20(3):639-645, doi: 10.21273/HORTTECH.20.3.639.

Knewtson, S.J.B., M.B. Kirkham, R.R. Janke, L.W. Murray, and E.E. Carey. 2012. Soil quality after eight years under high tunnels. HortScience 47(11):1630-1633, doi: 10.21273/ HORTSCI.47.11.1630.

Lamont, W.J. 2009. Overview of the use of high tunnels worldwide. HortTechnology 19(1):25-29, doi: 10.21273/ hortsci.19.1.25.

McElwee, G. and G. Bosworth. 2010. Exploring the strategic skills of farmers across a typology of farm diversification approaches. J. Farm Manag. 13(12):819-838.

Miles, M.B. and M. Huberman. 1994. Qualitative data analysis. 2nd ed. Sage, Thousand Oaks, CA.

Mount, P. 2012. Growing local food: Scale and local food systems governance. Agr. Human Values 29(1):107-121, doi: 10.1007/s10460-011-9331-0.

O'Connell, S., C. Rivard, M.M. Peet, C. Harlow, and F. Louws. 2012. High tunnel and field production of organic heirloom tomatoes: Yield, fruit quality, disease, and microclimate. HortScience 
47(9):1283-1290, doi: 10.21273/ hortsci.47.9.1283.

Rudisill, M.A., B.P. Bordelon, R.F. Turco, and L.A. Hoagland. 2015. Sustaining soil quality in intensively managed high tunnel vegetable production systems: A role for green manures and chicken litter. HortScience 50(3):461-468, doi: 10.21273/ hortsci.50.3.461.

Stake, R.E. 1995. The art of case study research. Sage, Thousand Oaks, CA.

Sydorovych, O., C.L. Rivard, S. O'Connell, C.D. Harlow, M.M. Peet, and F.J. Louws. 2013. Growing organic heirloom tomatoes in the field and high tunnels in North Carolina: Comparative economic analysis. Hort Technology 23(2):227-236, doi: 10.21273/horttech.23.2.227.
Thilmany, D., E. Canales, S.A. Low, and K. Boys. 2021. Local food supply chain dynamics and resilience during COVID-19. Appl. Econ. Perspect. Policy 43(2):86-104, doi: 10.1002/aepp.13121.

U.S. Department of Agriculture, National Agricultural Statistics Service. 2021. Census of horticulture. 19 Mar. 2021. <https:// www.nass.usda.gov/Surveys/Guide_to_NA SS_Surveys/Census_of_Horticultural_Speci alties/index.php $>$.

Valliant, J.C.D., J.R. Farmer, S.L. Dickinson, A.B. Bruce, and J.M. Robinson. 2017. Family as a catalyst in farms' diversifying agricultural products: A mixed methods analysis of diversified and nondiversified farms in Indiana, Michigan and Ohio. J. Rural Stud. 55(1):303-315, doi: 10.1016/j.jrurstud.2017.08.017.
Vescera, M. and R.N. Brown. 2016. Effects of three production systems on muskmelon yield and quality in New England. HortScience 51(5):510-517, doi: 10.21273/HORTSCI.51.5.510.

Waldman, K.B., D.S. Conner, J.A. Biernbaum, M.W. Hamm, and A.D. Montri. 2012. Determinants of hoophouse profitability: A case study of 12 novice Michigan farmers. HortTechnology 22(2):215-223, doi: 10.21273/HORTTECH.22.2.215.

Whatmore, S. 1994. Farm household strategies and styles of farming: Assessing the utility of farm typologies, $\mathrm{p}$. 31-37. In: J.D. van der Ploeg and A. Long (eds.). Born from within-practice and perspectives of endogenous rural development. Van Gorcum, Assen, The Netherlands. 